Article

\title{
Different Scenarios for the National Transmission Grid, Considering the Extensive Use of On-Site Renewable Energy in the Mexican Housing Sector
}

\author{
Ivan Oropeza-Perez * and Astrid H Petzold-Rodriguez
}

Citation: Oropeza-Perez, I.; Petzold-Rodriguez, A.H Different Scenarios for the National Transmission Grid, Considering the Extensive Use of On-Site Renewable Energy in the Mexican Housing Sector. Energies 2021, 14, 195. https://doi.org/10.3390/en14010195

Received: 24 November 2020 Accepted: 26 December 2020 Published: 2 January 2021

Publisher's Note: MDPI stays neutral with regard to jurisdictional clai$\mathrm{ms}$ in published maps and institutional affiliations.

Copyright: (C) 2021 by the authors. Licensee MDPI, Basel, Switzerland. This article is an open access article distributed under the terms and conditions of the Creative Commons Attribution (CC BY) license (https:// creativecommons.org/licenses/by/ $4.0 /)$.
Department of Architecture, Universidad de las Americas Puebla, Ex Hacienda Sta. Catarina Martir, San Andrés Cholula, Puebla 72810, Mexico; astrid.petzold@udlap.mx

* Correspondence: ivan.oropeza@udlap.mx; Tel.: +52-222-229-3253

Abstract: The Mexican national electricity transmission and distribution grid (SEN, initials in Spanish) is characterized by the high interconnection between its several electricity generation plants and the millions of final consumers throughout the country. This feature, which is seen first as an adequate transmission and distribution method for electricity between producer and consumer, has the inconvenience of being highly complex when renewable energy is introduced into the SEN. The random nature of renewable energy means that coordination between the producer and consumer is difficult; therefore, these energy sources are considered by the Mexican Federal Commission of Electricity (CFE, initials in Spanish) without priority in their generation and distribution. In this document, a solution for this is given by the consideration of on-site photovoltaic production in the Mexican residential sector, setting a straightforward relationship between production and consumption, neglecting the long-distance transmission, and freeing the transmission and distribution through the SEN at certain hours of the day. Different scenarios are studied, considering the level of penetration of this renewable energy technology into the housing sector. In this way, it is found that, if $80 \%$ of the total Mexican dwellings hold a photovoltaic roof, in some seasons of the year, a large part the total national demand can be fulfilled by the photovoltaic generation if certain systems—-such as bidirectional smart meters-are applied. In this sense, the results show that, if $80 \%$ of the Mexican dwellings had a photovoltaic roof, there would be a money saving of 3418 Million USD and a mitigation of 25 million tons $\mathrm{CO}_{2} \mathrm{e}$, for 2018. With this, it is concluded that renewable energy in Mexico could provide a much greater share if the electricity is produced in the same place where it will be consumed. This might be possible in Mexico due to the high interconnection of the transmission and distribution grid, which would manage the surplus electricity generation in the dwellings in a proper manner.

Keywords: extensive use of on-site renewable-energy; national transmission and distribution grid; economical and environmental benefits

\section{Introduction}

The world is under an energy transition from conventional to renewable and clean energy sources. The countering of global climate change and the reduction of energy poverty are the main reasons to carry out this transition [1]. Nevertheless, this conversion is not being carried on in an equal manner amongst the nations. While some countries are already about to reach a $100 \%$ renewable energy scenario [2-7], and others are in the transition [8-13], some have not reached even 10\% [14-17]. Among many other reasons, such as economical [18-21], social [22,23], political [24-26], technical [27], or multicriteria issues [28], renewable and low-carbon energies are not easy to implement in national and large-scale scenarios.

Due to its random production, which is dependent on the climate conditions, the consumption of the renewable energy (wind and solar, mainly) can be summed up by the 
phrase 'use it or lose it' [29], giving only few options of consumption if it is not instantly used [30]. Energy storage and smart grids are the most mentioned solutions in the literature review [31]. Moreover, other technical issues-such as the load frequency variation of the electrical current-have to be addressed in order to dispatch proper and reliable electricity [32]. In this sense, innovative approaches of renewable energy management have been developed in recent years [33].

In addition, the complexity of a national transmission and distribution grid makes the implementation of renewable energies in a national scenario more difficult. Whereas the use of renewable energy is working properly in local and small scenarios, a national electricity system does not allow us to coordinate the activity of generation and consumption [34].

This is the case for the Mexican electricity system, which is still dominated by fossilfuel-based generation, as it considers this source "more reliable and controllable" due to its continuous working hours [35,36]. Moreover, although there is a national goal to achieve a share of $35 \%$ renewable energy by 2024 , different challenges, including the coordination of the transmission and distribution grid [37], are still a brake to reaching such an achievement.

Furthermore, in the literature review, to the best of our knowledge, a study was not found that shows an analysis of the extensive implementation of renewable energy at a small scale, especially in the housing sector, and what would be the corresponding benefits of this implementation.

Due to these reasons, in this document, the extensive use of on-site renewable energy is proposed for the Mexican housing sector, instead of medium and large renewableenergy plants that introduce their generated electricity to the SEN, yielding their priority to fossil-fuel-based electricity.

For this, a model for the estimation of the generated electricity on an annual basis considering the extensive implementation of photovoltaic (PV) roofs is necessary. Furthermore, the model also calculates the instantaneous electricity demand compared to the instantaneous electricity generation of the PV roofs, considering the national average solar radiation.

As such, different scenarios are considered in order to determine their influence on the Mexican electricity sector. These scenarios comprise the level of penetration of PV roofs into Mexican households. In each scenario, an analysis of the energy saving, the $\mathrm{CO}_{2}$ mitigation, and the cost reductions of the transmission and distribution grid are estimated. Finally, the feasibility and affordability of the implementation is discussed, considering a costs/benefits study of the different scenarios.

The advantage of the model is seen in the novel analysis of the renewable energy usage in the Mexican electricity scenario, while the disadvantage is focused on the lack of accuracy due to the general approach considered in the document. Nevertheless, we believe that the analysis proposed here would help to show the main benefits of the extensive implementation of renewable electricity generation in the Mexican housing sector. A synthetized flowchart of the methodology can be seen in Figure 1.

The first two steps of the flowchart are focused on the 2018 status of the transmission and distribution grid, and the electricity generation of each source in Mexico. 


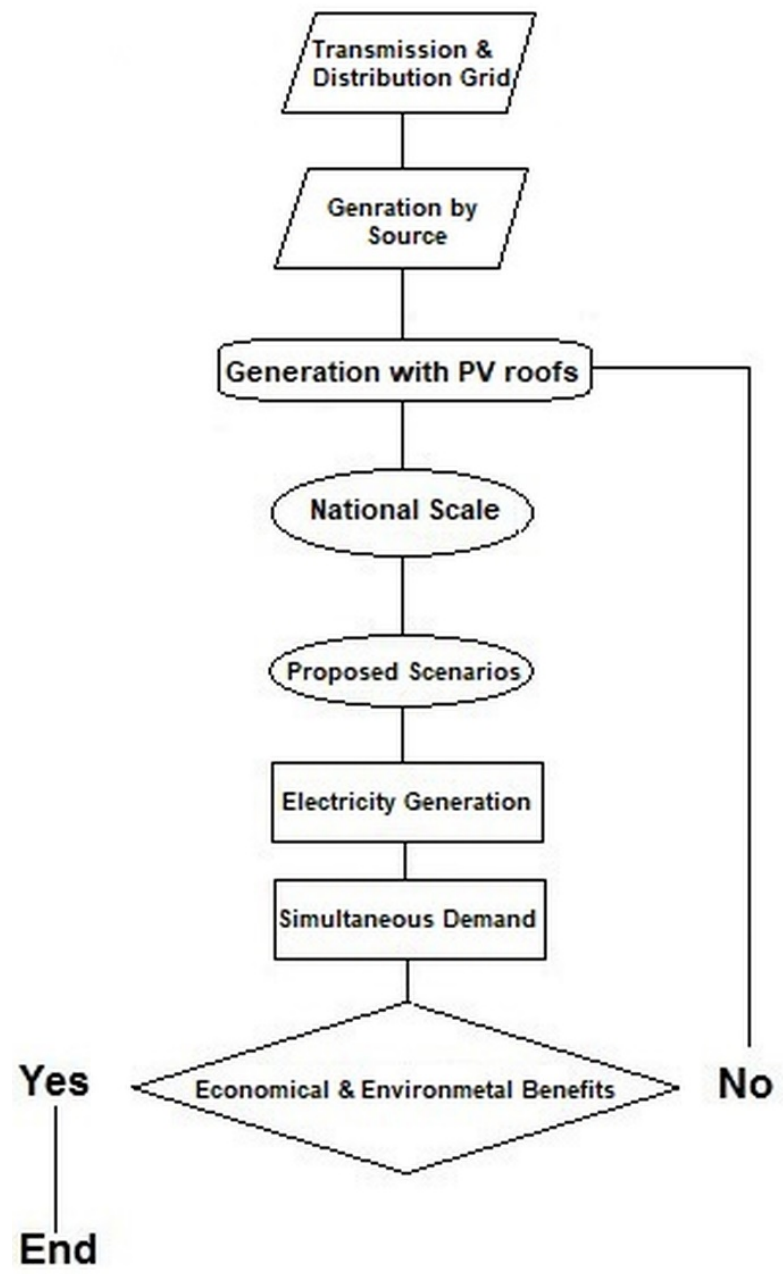

Figure 1. Methodology flowchart of the approach presented in this document.

\section{Materials and Methods}

\subsection{National Transmission and Distribution Grid}

The Mexican national electricity sector is run by the Mexican Federal Commission of Electricity (CFE, initials in Spanish), a government-owned company that has shared the electricity generation with private companies since the so-called Mexican Energy Reform was issued in 2013. Nonetheless, the SEN (transmission and distribution grid) is completely managed by the CFE through the National Center of Energy Control (CENACE, initials in Spanish).

One characteristic of the SEN is the high level of interconnection between the generators and consumers throughout the entire country. The SEN comprises four interconnected systems in the following Mexican municipalities:

- National Interconnected System (NIS): from Puerto Peñasco, in the northern state of Sonora, to Cozumel, in the southern state of Quintana Roo. This is the biggest Mexican interconnected system.

- Baja California Interconnected System (BCIS) comprises the municipalities of Ensenada, Tijuana, Tecate and Mexicali, in the state of Baja California, and San Luis Rio Colorado, in the state of Sonora. Furthermore, this system is interconnected to the Western Electricity Coordinating Council (WECC) of California, USA.

- Baja California Sur Interconnected System (BCSIS): from the municipality of Loreto to Los Cabos, in the state of Baja California Sur. This system is completely insolated.

- Mulege Interconnected System (MIS): from the municipality of Mulege to Bahia de Todos los Santos, in the state of Baja California Sur. This system is completely insolated. 
Furthermore, the NIS has 11 international interconnections with the following gates:

- United States of America: Ribereña-Ascarate, Anapra-Diablo, Ojinaga-Presidio, Piedras

Negras-Eagle-Pass, Nuevo-Laredo-Laredo, Cumbres F.-Railroad, Cumbres F.-Planta

Frontera, Matamoros-Brownsville and Matamoros-Military.

- Belize: Xul Ha-West.

- Guatemala: Tapachula-Los Brillantes.

The biggest interconnected system is the NIS, which embraces the Mexican continental territory $(92.7 \%)$, while the BCIS, BCSIS and MIS are located at the Baja California peninsula, sharing only $7.3 \%$ of the national territory. In terms of population, in 2018, the NIS managed the electricity of $122,483,587$ Mexicans ( $96.4 \%$ of the total population), while the other three systems provided electricity to $4,608,055$ people (3.6\%). A map of the SEN can be seen in Figure 2.

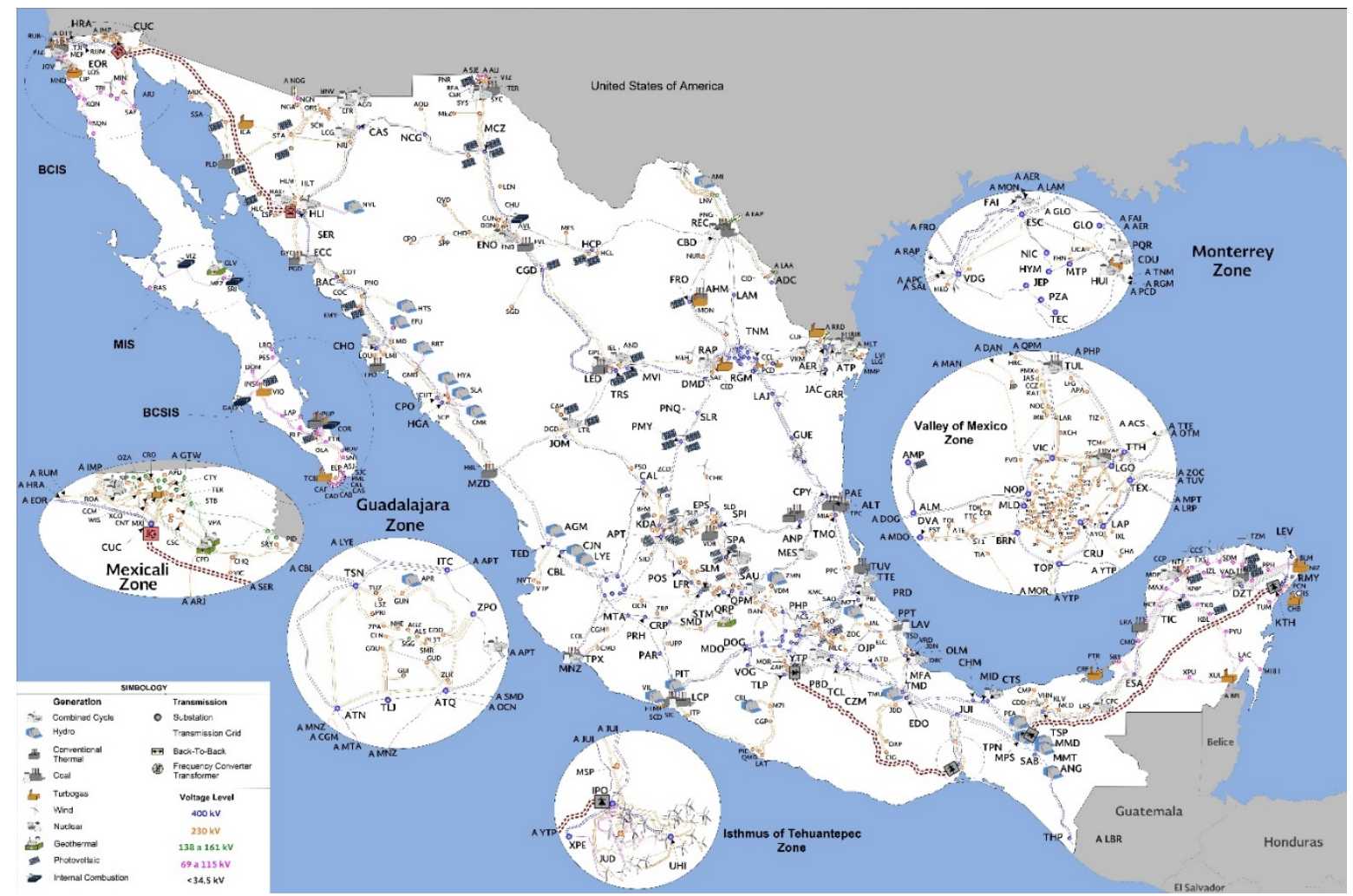

Figure 2. Mexican national electricity transmission and distribution grid. The peninsula of Baja California comprises the BCIS, MIS and BCSIS (source: CENACE [38], translation: own).

The SEN—comprising NIS, BCIS, BCSIS and MIS—can also be divided into transmission and distribution grids. The national transmission grid is considered to be for longdistance electricity transportation $(200-500 \mathrm{~km})$, with a voltage level range of $69-400 \mathrm{kV}$, whereas the general distribution grid (to be dispatched to the final consumers) is considered to be for medium-distance transportation (10-50 km), with a voltage level range of 1-35 kV. In 2018, the national transmission grid had a length of 108,018 km, while the general distribution grid had a total length of $512,520 \mathrm{~km}$ [38].

\subsection{Renewable Energy Generation through the Transmission and Distribution Grid}

In order to analyze the renewable energy technologies in Mexico, an analysis of all of the generation technologies used in Mexico was carried out. In 2018, the installed capacity of generation in the country was 70,053 MW. The distribution according to the type of technology can be seen in Table 1 . 
Table 1. Installed capacity of electricity generation in Mexico in 2018 [38].

\begin{tabular}{ccc}
\hline Technology & Installed Capacity (MW) & Share of Capacity (\%) \\
\hline Combined cycle & 25,569 & 36.5 \\
Hydroelectricity & 12,610 & 18.0 \\
Conventional thermal & 11,909 & 17.0 \\
Coal-fired & 5394 & 7.7 \\
Wind & 4764 & 6.8 \\
Turbogas & 3222 & 4.6 \\
Photovoltaic & 1821 & 2.6 \\
Nuclear & 1611 & 2.3 \\
Efficient cogeneration & 1401 & 2.0 \\
Geothermal & 701 & 1.0 \\
Internal combustion & 701 & 1.0 \\
Bioenergy & 350 & 0.5 \\
Total & 70,053 & 100 \\
\hline
\end{tabular}

From Table 1, one can notice that only $28.9 \%$ out of the 70,053 MW installed capacity in Mexico can be considered to be clean and/or renewable, i.e., the technologies of hydroelectricity, wind, PV, geothermal and bioenergy. Nevertheless, it is worthwhile to mention that, during 2018, PV and wind had an increase of 1316 MW and 942 MW, respectively, owning the highest growth rates among the other technologies [38].

This is because in Mexico, as was aforementioned, in 2013, an Energy Reform was issued to allow private electricity generation. In this sense, several companies started to produce electricity with wind, PV, and natural-gas-based technology, mainly, along with the so-called 'Independent Producers', who-since 1992-have had permission to generate electricity with various technologies (mainly fossil-fuel based) for the following purposes: (a) to sell it to CFE, (b) to export it, and (c) for self-consumption. In none of these three cases should the activities be considered as an economic competition to CFE. With the Energy Reform, however, private companies were allowed to generate electricity with a higher profit than the Independent Producers, due to the CFE paying a higher cost for each MWh produced [39].

Nevertheless, in the case of private electricity generation, the companies have to pay the CFE a fee for the electricity transmission and distribution. This cost is called a 'porting fee', and has to be covered regardless of the generation technology. Because of this reason, several renewable energy companies filed a dispute to the Mexican Supreme Court of Justice in 2020 against the porting fee, claiming that this payment "discourage the clean energy production in Mexico".

Furthermore, due to the random nature of renewable energy production, the CENACE has difficulties in dispatching this generated electricity, especially during hours of low demand, i.e., 23-9 $\mathrm{h}$ the next day. For a typical summer day, an average of 36,982 MW is registered during low demand, while the daily average is 39,629 MW, with a maximum peak of 42,873 MW at 17:00 $\mathrm{h}$ [40].

As such, the CENACE requires that the electricity from private companies:

... must be incorporated [to the SEN] by means of the intervention and backup of power plants with total [electricity generation] availability and that dispatch planning and operation reservoirs, as well as related services that make its feasible performance, which requires of the correct specification of the associated products required in order to give more certainty to all the market stakeholders [41].

In this sense, renewable energies struggle to be dispatched because their production is lower compered to fossil-fuel-based energies. In Table 2, the average hours of working of each generation technology is displayed. 
Table 2. Average working hours of the generation technologies in Mexico, in 2018 [38].

\begin{tabular}{cccc}
\hline Technology & $\begin{array}{c}\text { Energy Produced } \\
\text { (GWh) }\end{array}$ & $\begin{array}{c}\text { Working Hours at } \\
\text { Year }\end{array}$ & $\begin{array}{c}\text { Percentage of Work } \\
\text { at Year (\%) }\end{array}$ \\
\hline Combined cycle & 161,812 & 6328 & 72.2 \\
Hydroelectricity & 32,362 & 2566 & 29.3 \\
Conventional thermal & 41,881 & 3517 & 40.1 \\
Coal-fired & 29,190 & 5411 & 61.8 \\
Wind & 12,373 & 2597 & 29.7 \\
Turbogas & 8567 & 2659 & 30.4 \\
Photovoltaic & 2221 & 1220 & 13.9 \\
Nuclear & 13,643 & 8469 & 96.7 \\
Efficient cogeneration & 6980 & 4982 & 56.9 \\
Geothermal & 5395 & 7694 & 87.8 \\
Internal combustion & 2221 & 3168 & 36.2 \\
Bioenergy & 635 & 1813 & 20.7 \\
\hline
\end{tabular}

From Table 2, one can see that combined cycle technology, based on natural gas, has a high working rate compared to wind and PV. This can explain the belief that natural-gasbased generation is seen as more 'controllable' than renewable generation [35], especially when unexpected demands are presented. This, along with the porting fee, means that renewable energy in Mexico is still seen as an expensive and unreliable technology.

\subsection{Loss on the Transmission and Distribution Grid}

Moreover, another obstacle that the generators have, private or public, is the electricity loss throughout the transmission and distribution grid. In the case of Mexico in 2018, this loss is divided as shown in Table 3.

Table 3. Electricity loss in the transmission and distribution grid in Mexico, in 2018 [38].

\begin{tabular}{cccc}
\hline Production (GWh) & $\begin{array}{c}\text { Loss onto Transmission Grid } \\
\text { (GWh) }\end{array}$ & $\begin{array}{c}\text { Loss onto Distribution Grid } \\
\text { (GWh) }\end{array}$ & Final Consumption (GWh) \\
\hline 318,236 & 33,669 & 15,756 & 268,811 \\
\hline
\end{tabular}

According to Table 3, the total loss in Mexico in 2018 was 15.53\% of the total generated electricity. In the transmission grid, mostly by the wires and transformation facilities heating, was $10.58 \%$ out of the total generated electricity, whereas in the distribution grid, mostly by incidents of thieving and mismeasuring, was $4.95 \%$ out of the total generation.

As such, as it can be seen, renewable energies in Mexico have their most challenging phase on the transmission and distribution grid, which is not under their management. This, additional to their random generation, makes that these kind of technologies look for innovative solutions.

Therefore, in this document, for renewable energy technologies, a solution approach for the inconvenience of the porting fee, the lack of priority given by the CENACE, and the loss throughout the SEN is given by the extensive installation of PV roofs in the Mexican residential sector. This is expected to reduce the transportation of electricity at long and medium distance $(10-500 \mathrm{~km})$, to use the electricity in the moment that it is generated, and to dispense with the porting fee.

\subsection{PV Roof Technology}

As was already mentioned, the extensive placement of PV cells on the roofs of the Mexican housing sector is proposed. The first purpose of this is to avoid the use of the transmission grid at long and medium distances. A general scheme of the proposed PV technology is displayed in Figure 3: 


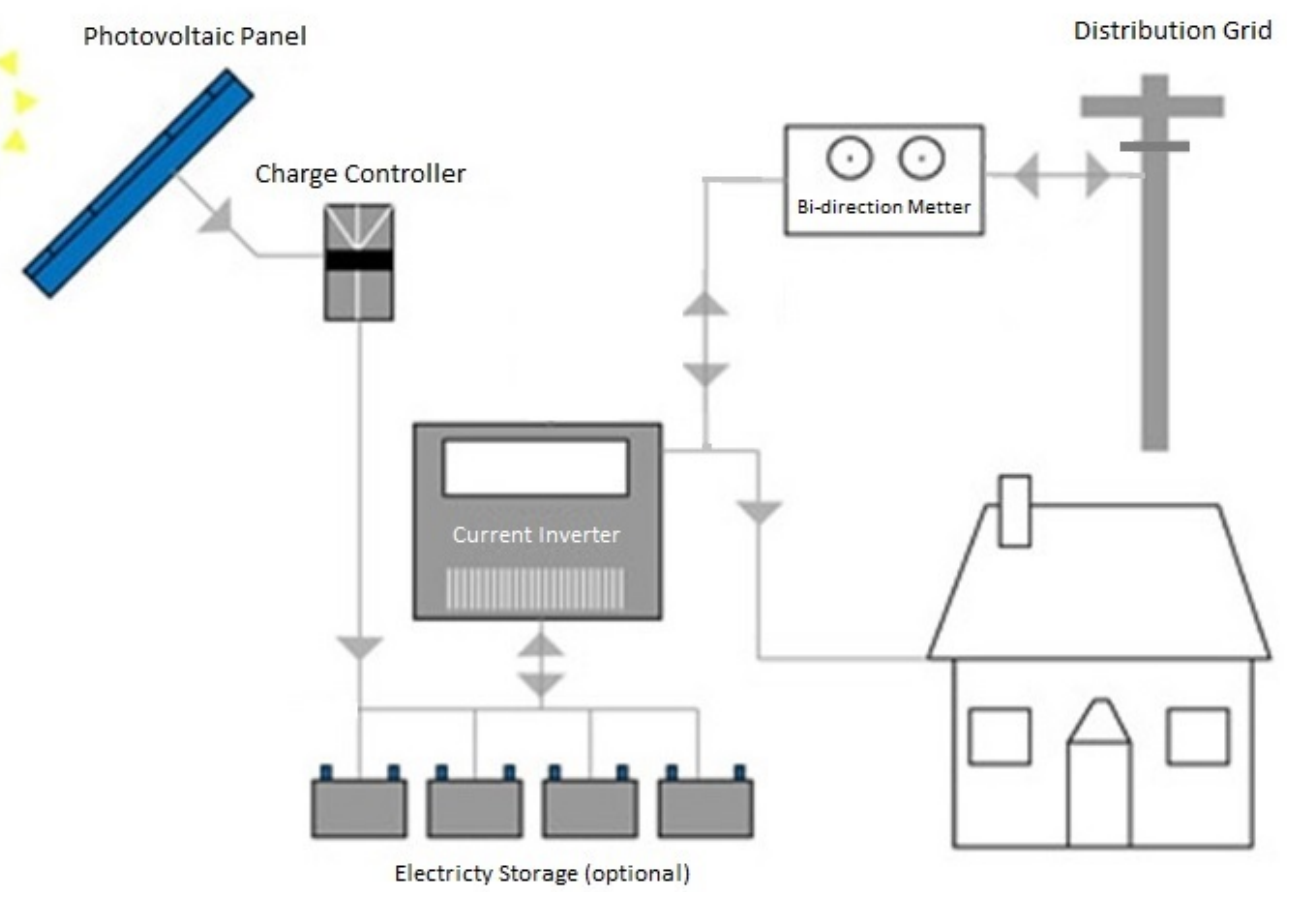

Figure 3. Proposed PV roof technology in the Mexican residential sector.

The proposed technology comprises the use of electricity storage to be consumed at short and medium times. Nevertheless, the main approach of the PV generation is the incorporation of the surplus generated energy into the distribution grid, managed by CENACE. This is expected to liberate the transmission grid if the PV roofs are applied in an extensive manner in the country.

\subsection{Available Roofs in the Mexican Residential Sector}

In 2018, there were approximately 34.73 million dwellings allocated in the Mexican residential stock. According to the National Survey of Households Incomes and Expenditures 2018 (abbreviated to ENIGH in Spanish) from the Mexican National Institute of Statistics and Geography (abbreviated to INEGI in Spanish), the distribution according to the type of construction is shown in Table 4.

Table 4. Number of households in Mexico in 2018 [42].

\begin{tabular}{ccccc}
\hline & $\begin{array}{c}\text { Total } \\
\text { Households }\end{array}$ & $\begin{array}{c}\text { Detached and } \\
\text { Semi-Detached } \\
\text { Households }\end{array}$ & $\begin{array}{c}\text { Apartments in } \\
\text { Multi-Story } \\
\text { Buildings }\end{array}$ & $\begin{array}{c}\text { Communal Houses } \\
\text { and Nonresidential } \\
\text { Rooms }\end{array}$ \\
\hline Percentage $(\%)$ & $\begin{array}{c}34,735,833 \\
100.0\end{array}$ & $\begin{array}{c}32,443,268 \\
93.4\end{array}$ & $1,736,792$ & 555,773 \\
\end{tabular}

From Table 4, one can easily notice that more than $93 \%$ of the households in Mexico are able, in principle, to install PV technology in their roof, considering that detached and semi-detached houses have an independent roof, where Mexican people install water and gas tanks [42].

In the case of apartments, most of the households with this type of construction are located at the greater metropolitan area of Mexico City (1.58 million apartments) [42]. If it is considered that an apartment building in Mexico City is, on average, four stories high according to the Mexican National Housing Commission (CONAVI, abbreviation in Spanish) [43], and that 1 out of 4 apartments has an independent roof, 395,933 roofs might be available for the installation of PV cells. 
As such, neglecting communal and nonresidential rooms, in 2018 there were approximately 32.73 million roofs available for solar renewable energy, if it is also considered that approximately 100,000 dwellings already had this kind of technology in the country in the same year [44].

\subsection{Architypes of Dwellings in Mexico}

According to the ENIGH, Mexican households can be divided by their size and their number of occupants, as is displayed in Tables 5 and 6 .

Table 5. Distribution of Mexican dwellings according to their built area [42].

\begin{tabular}{ccccc}
\hline Built Area $\left(\mathbf{m}^{\mathbf{2}}\right)$ & $\leq \mathbf{4 5}$ & $\mathbf{4 6 - 1 0 0}$ & $>\mathbf{1 0 0}$ & Total \\
\hline No. Dwellings & $3,681,998$ & $16,291,106$ & $14,762,729$ & $34,735,833$ \\
Share of total $(\%)$ & 10.6 & 46.9 & 42.5 & 100.0 \\
\hline
\end{tabular}

Table 6. Distribution of Mexican dwellings according to their number of occupants [42].

\begin{tabular}{cccccc}
\hline No. Occupants & $\mathbf{1 - 2}$ & $\mathbf{3 - 5}$ & $\mathbf{6 - 8}$ & $\mathbf{2}$ & Total \\
\hline No. Dwellings & $7,850,298$ & $19,903,632$ & $5,766,148$ & $1,215,754$ & $34,735,833$ \\
Share of total $(\%)$ & 22.6 & 57.3 & 16.6 & 3.5 & 100.0 \\
\hline
\end{tabular}

In Tables 5 and 6 , three kinds of architypes are proposed for the present study, namely small (architype 1), medium (architype 2) and large (architype 3). These three architypes assume a uniform distribution of the number of occupants concordant with the building size, assuming that a small house shelters few people, and vice versa. As such, the distribution is the following:

- Architype 1: in all dwellings of $\leq 45 \mathrm{~m}^{2}$ live families of 1-2 people.

- Architype 2: families of 1-5 people live in dwellings of $<45 \mathrm{~m}^{2}$.

- Architype 3: all families of $>5$ people live in dwellings of $>100 \mathrm{~m}^{2}$.

Small numbers of people living in a large dwelling and many people living in a small household are neglected, even though these situations might be present in the country [42]. As such, Table 7 can be constructed. The table assumes that 32.73 million dwellings are able to have a PV roof in 2018, neglecting apartments, non-residential rooms, and households with installed PV.

Table 7. Architypes of available dwellings in Mexico in 2018.

\begin{tabular}{cccc}
\hline & Architype 1 & Architype 2 & Architype 3 \\
\hline No. Dwellings & $3,015,331$ & $23,405,266$ & $6,315,235$ \\
Share of total (\%) & 9.2 & 71.5 & 19.3 \\
\hline
\end{tabular}

For each architype, two respective levels of consumption and generation are proposed. These levels are estimated based on the average number of occupants, in the case of consumption, and based on the average roof surface, in the case of generation.

For the calculation of the consumption, it is assumed that, in Mexico, in 2018, there was a consumption in the residential sector of around 62,000 GWh [38]. In the same year, the population was 126.2 million inhabitants [38]. With this, a yearly average consumption of $491.3 \mathrm{kWh}$ per capita is supposed. It is worthwhile to mention that this consumption is only in the residential sector, neglecting the other energy activities of Mexicans (industry, commercial etc.).

In order to calculate the generation, the average national irradiance in the Mexican territory was taken into account, i.e., $5.3 \mathrm{kWh} / \mathrm{m}^{2}$ per day [45]. Furthermore, if the average efficiency of the PV cells is set at $17.3 \%$ [46] (considering this figure as the most common 
amongst commercial PV cells, i.e., polycrystalline silicon cells), the electricity generation is estimated as follows [46]:

$$
\begin{gathered}
P V_{\text {eff }}=\frac{P_{\text {out }}}{P_{\text {in }}} \\
P_{\text {out }}=P V_{\text {eff }} \cdot P_{\text {in }}
\end{gathered}
$$

where $P V_{\text {eff }}$ is the efficiency of the PV cell (dimensionless); $P_{\text {out }}$ is output power, i.e., the generated electricity $(\mathrm{kWh})$; and $P_{\text {in }}$ is the input power, i.e., the solar radiation $(\mathrm{kWh})$. Therefore, if the average irradiance is given in $\mathrm{kWh} / \mathrm{m}^{2}$ per day, the annual electricity production by $\mathrm{m}^{2}$ is set as $334.7 \mathrm{kWh} / \mathrm{m}^{2}$.

As such, considering the average consumption of $491.3 \mathrm{kWh} /$ person and the average generation of $334.7 \mathrm{kWh} / \mathrm{m}^{2}$, Table 8 was constructed. For each architype, an average number of persons (consumption) and an average PV-cell surface (generation) was considered as follows:

- $\quad$ Architype 1: ocupants, 1.3. PV-cell surface, $2.0 \mathrm{~m}^{2}$.

- Architype 2: occupants, 3.5. PV-cell surface, $5.2 \mathrm{~m}^{2}$.

- $\quad$ Architype 3: occupants, 5.3. PV-cell surface, $7.9 \mathrm{~m}^{2}$.

Table 8. Average annual consumption and generation of the three architypes of dwellings.

\begin{tabular}{cccc}
\hline & Architype 1 & Architype 2 & Architype 3 \\
\hline Consumption $(\mathrm{kWh})$ & 638.7 & 1719.6 & 2603.9 \\
Generation $(\mathrm{kWh})$ & 669.4 & 1740.4 & 2644.1 \\
\hline
\end{tabular}

The number of occupants was estimated based on Table 6, whereas the average surface of the PV cells was calculated according to the average consumption of each architype, estimated from a backward calculation of the mean number of occupants, considering that the electricity production must cover the total consumption of the dwelling. In this way, Table 8 was constructed.

As such, with these three proposed architypes, along with their respective consumptions and generations, three different scenarios of extensive PV roof installation in Mexico were carried out.

\section{Results}

\subsection{Scenarios for Extensive PV Installation in Mexico}

Three scenarios of extensive PV-roof installation in the Mexican housing sector are hereby proposed. These scenarios are designed according to the current characteristics of technical feasibility and affordability within the Mexican context. In this sense, ten governmental programs were carried out in the residential sector in order to save energy, from 1990 to 2017 [47], which mainly focused on illumination and refrigeration. Amongst these programs there is Daylight Saving Time (DST, Horario de Verano, translation into Spanish), issued in 1996, the results of which were an average annual savings of around $1100 \mathrm{GWh}$ since its implementation [47], which is very related to energy savings in illumination.

Furthermore, since the Energy Reform was issued, the participation of private companies in electricity generation in Mexico has considerably increased. In this sense, seven large PV installations (from 100 to $362.96 \mathrm{MW}$ of installed capacity) have been placed since 2013, with more projects by private companies planned for the coming years [39].

As such, if it is considered that the extensive PV-roof installation program could be issued with the support of the Mexican Government and private companies, alone and/or together, three preliminary scenarios are proposed, as can be seen in Table 9. 
Table 9. Three scenarios of extensive PV-roof installation in Mexico.

\begin{tabular}{cccc}
\hline & Scenario A & Scenario B & Scenario C \\
\hline No. Dwellings & $26,188,666$ & $13,094,333$ & $6,547,167$ \\
Share (\%) & 80 & 40 & 20 \\
\hline
\end{tabular}

As such, considering the respective share of the three architypes, multiplied by the respective average energy consumption and production of each architype, Tables 10-12 were constructed. It is worthwhile to remark that the estimated generated electricity might be fully exploited if some technologies are applied. These technologies are mainly two: electricity storage, and the use of a bidirectional meter (cf. Figure 3) which allows the distribution manager (in this case, the CENACE) to dispatch the surplus generation to another consumer who requires the electricity at the very same time, taking advantage of the interconnected distribution gird.

Table 10. Average annual consumption and generation of the three architypes of dwellings in Mexico, in 2018, for scenario A.

\begin{tabular}{ccccc}
\hline & Architype 1 & Architype 2 & Architype 3 & Total \\
\hline No. Dwellings & $2,412,265$ & $18,724,213$ & $5,052,188$ & $26,188,666$ \\
Consumption (GWh) & 1540.7 & $32,198.2$ & $13,155.4$ & $46,894.3$ \\
Generation (GWh) & 1614.8 & $32,587.6$ & $13,358.5$ & $47,560.9$ \\
\hline
\end{tabular}

Table 11. Average annual consumption and generation of the three architypes of dwellings in Mexico, in 2018 , for scenario B.

\begin{tabular}{ccccc}
\hline & Architpye 1 & Architype 2 & Architype 3 & Total \\
\hline No. Dwellings & $1,206,133$ & $9,362,107$ & $2,526,094$ & $13,094,333$ \\
Consumption (GWh) & 770.4 & $16,099.1$ & 6577.7 & $23,447.1$ \\
Generation (GWh) & 807.4 & $16,293.8$ & 6679.2 & $23,780.4$ \\
\hline
\end{tabular}

Table 12. Average annual consumption and generation of the three architypes of dwellings in Mexico, in 2018 , for scenario C.

\begin{tabular}{ccccc}
\hline & Architpye 1 & Architype 2 & Architype 3 & Total \\
\hline No. Dwellings & 603,066 & $4,681,053$ & $1,263,047$ & $6,547,167$ \\
Consumption (GWh) & 385.2 & 8049.5 & 3288.8 & $11,723.6$ \\
Generation (GWh) & 403.7 & 8146.9 & 3339.6 & $11,890.2$ \\
\hline
\end{tabular}

From Tables 10-12, one can notice that the three scenarios generate a considerable amount of energy compared to the total consumption of electricity in the Mexican residential sector in 2018 (62,000 GWh). As such, scenario A would generate $76.71 \%$ of the consumption, scenario B would generate $38.36 \%$, and scenario C would generate $19.18 \%$. Any of these figures help to reduce long-distance electricity transmission and distribution, as well as fossil-fuel-based electricity generation in Mexico, which shares $71.1 \%$ of the total installed capacity of the country.

\subsection{National Demand and Generation}

One of the most important tasks of the CENACE is the planning of the transmission and distribution of the instant electricity demand in the Mexican territory. This planning is highly related to the SEN's performance, in which the electricity is transmitted and distributed towards the final consumers at the very same time it is generated.

As mentioned already, the national installed capacity in Mexico, in 2018, was 70.1 GW, when in a typical day an average of $34.4 \mathrm{GW}$ is registered during low demand, while the 
daily average is $37.0 \mathrm{GW}$, with a maximum peak of $40.6 \mathrm{GW}$. Moreover, during the $23 \mathrm{~h}$ week of 2018, the instant demand reached a maximum peak of $46.8 \mathrm{GW}$. In this sense, Figure 4 shows the national instant demand for the summer and winter solstice, 21 June and 21 December, respectively.

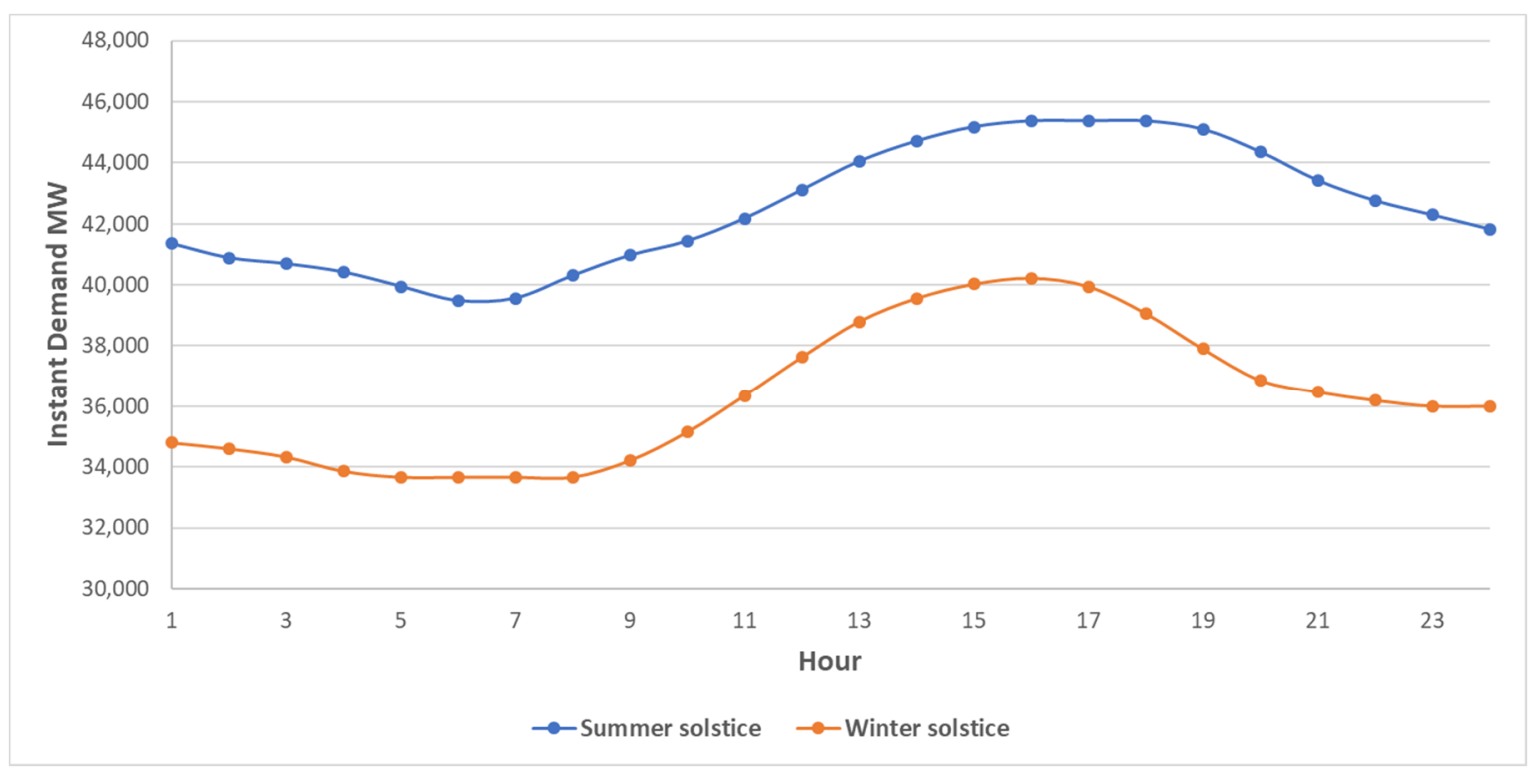

Figure 4. Instant demand for the summer and winter solstices in Mexico in 2018 [40].

According to Figure 4, the peak demand of the winter solstice occured at 16:00 h, GMT-6. This atypical hour is explained by the fact that Mexico shares three different times zones, i.e., GMT-6, GMT-7, and GMT-8. In this sense, times zones GMT-7 and GMT-8 haveto a great extent-air-conditioned dwellings, because most of their territory, including the Baja California Peninsula, presents arid and dry-tropic climate conditions. Both arid and dry-tropic conditions represent $69.9 \%$ of the total share of air-conditioning in the country $[48,49]$. Therefore, 16:00 h (GMT-6) represents the warmest hours for time zones GMT-7 and GMT-8 (14:00 and 15:00 h, respectively) increasing the electricity demand in terms of air-conditioning [40].

Moreover, when the DST is presented in Mexico, since the first Sunday of April until the last Sunday of October, coinciding with the cooling season, the times zones change to GMT-5, GMT-6, and GMT-7, respectively, with the exception of the northern state of Sonora and the southern state of Quintana Roo [50]. Thus, the peak of the electricity generation and consumption is delayed to 17:00-18:00 h, GMT-5 (Mexico City time zone), considering that the air-conditioned dwellings located at arid and dry-tropic conditions consume more energy at later hours. For the understanding of this situation, a map of Mexico with its time zones and main climate conditions can be observed in Figure 5.

From Figure 6, one can reaffirm that summer time, even in the DST program, is still the season with the higher electricity demand of the year, due to its being the warmer season, forcing the use of air-conditioning in a large part of the country. 


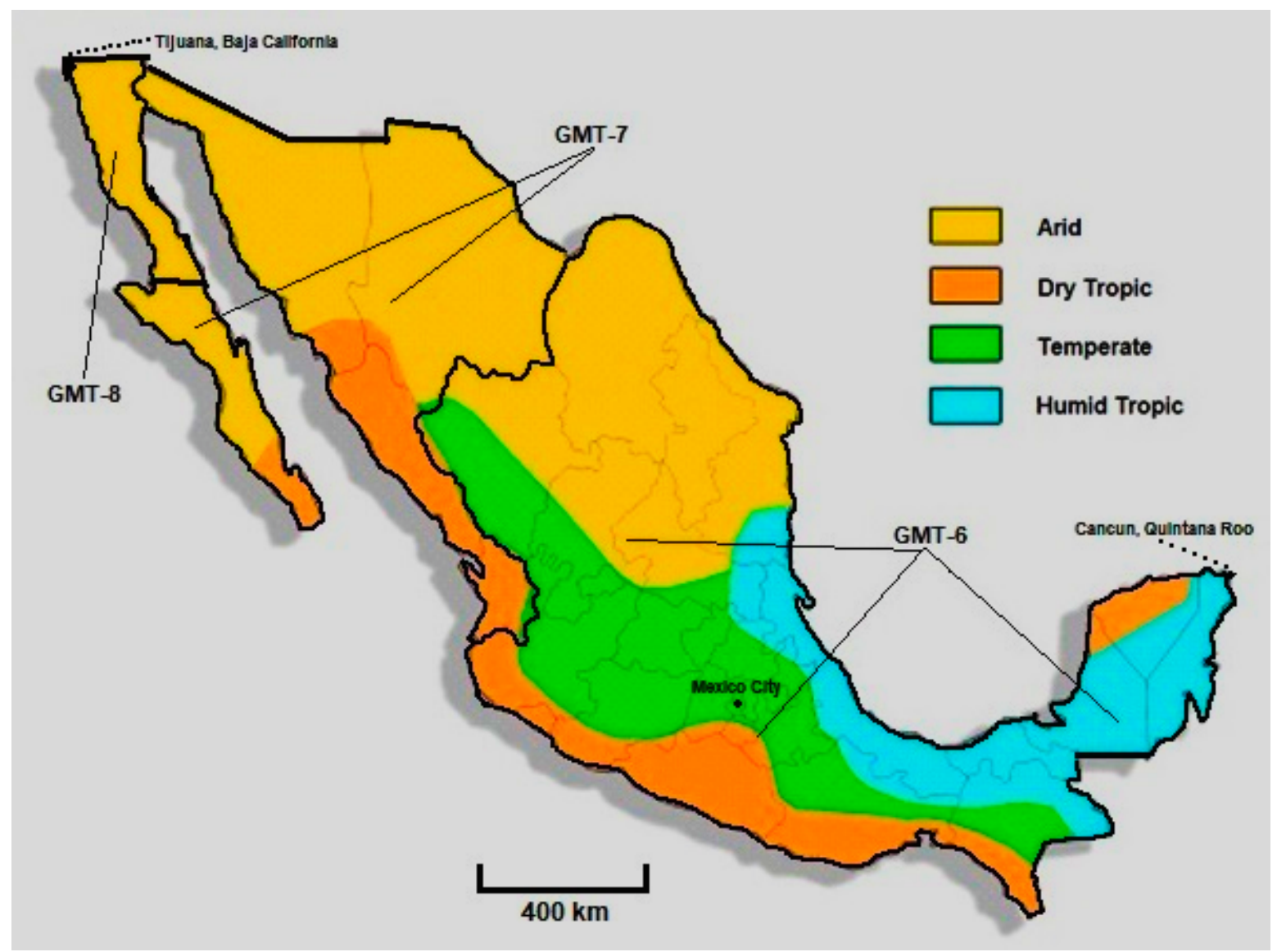

Figure 5. Climate conditions and time zones of Mexico without DST (source: own).

Furthermore, the annual hourly national demand in 2018 can be seen in Figure 6 .

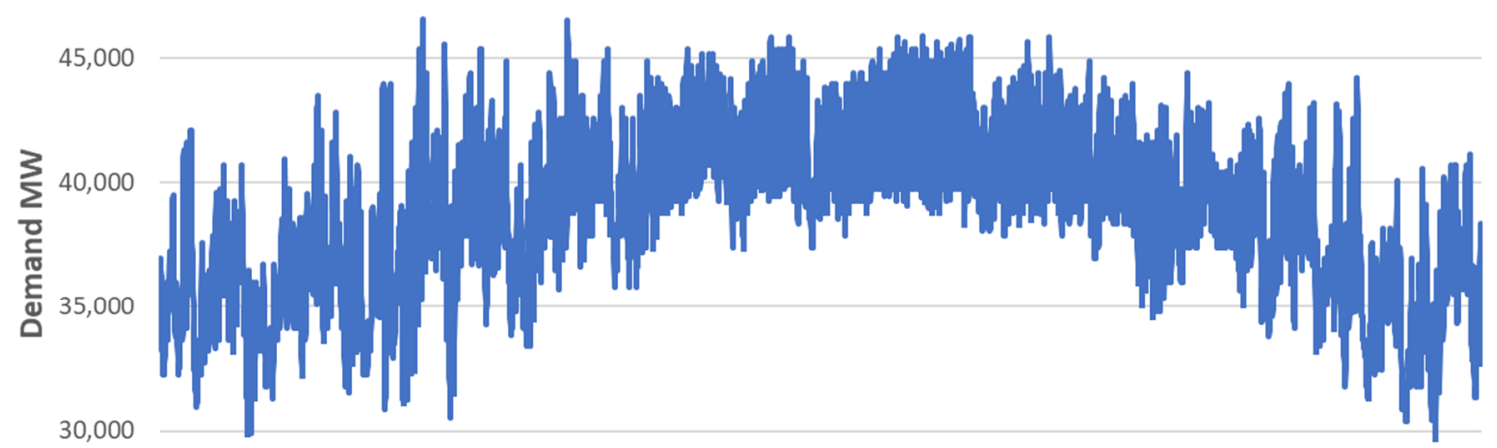

25,000

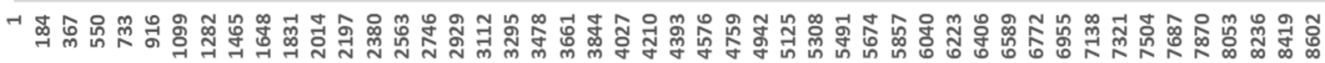 Hour}

Figure 6. National annual electricity demand in Mexico, in 2018 [40]. 


\subsection{National Demand Reduction}

By applying an extensive installation of PV roofs, it is expected that the instant national electricity demand will be decreased. With the three scenarios hereby developed, it is also expected that the respective instant demand will decrease compared to the actual net generation and demand. As such, two sample days were chosen: one considering DST (cooling season) and one without DST.

For this, the instant demand of the PV-roofs is calculated as follows:

$$
G_{\text {Instant }}=R_{\text {Mean }} \cdot P V_{\text {Surface }} \cdot P V_{E f f}
$$

where $G_{\text {Instant }}$ is the instant generation by the PV cell (W), $R_{\text {Mean }}$ is the mean national global solar radiation of Mexico at one hour specificly $\left(\mathrm{W} / \mathrm{m}^{2}\right)$, and $P V_{\text {Surface }}$ Architype $n$ is the surface of the PV cell according to the architype $\left(\mathrm{m}^{2}\right)$. As such, in order to calculate the national generation by the PV roofs, Equation (4) is developed:

$$
\begin{aligned}
N G_{\text {Scenario }}= & \sum_{n=1}^{\text {No.Dwelling Architype } 1} R_{\text {Mean }} \cdot P V_{\text {Surface Architype 1 }} \cdot P V_{E f f}+\sum_{n=1}^{\text {No.Dwelling Architype 2 }} R_{\text {Mean }} \\
& \cdot P V_{\text {Surface Architype 2 }} \cdot P V_{E f f}+\sum_{n=1}^{\text {No.Dwelling Architype 3 }} R_{\text {Mean }} \cdot P V_{\text {Surface Architype 3 }} \cdot P V_{E f f}
\end{aligned}
$$

where $N G_{\text {Scenario }}$ is the national instant generation (MW) by PV cells according the type of scenario (A, B and C) developed in this document. Both Equations (3) and (4) were developed for this document in particular.

From Figure 7, one can observe that the global solar radiation is higher and lasts longer during the summer solstice than the winter solstice. As such, it is possible to use PV technology to decrease the instant demand of electricity when it is more necessary, i.e., the cooling season. As such, by applying Equation (4), the instant national demand and generation by the PV roofs-considering the proposed scenarios-can be displayed for the summer and winter solstice.

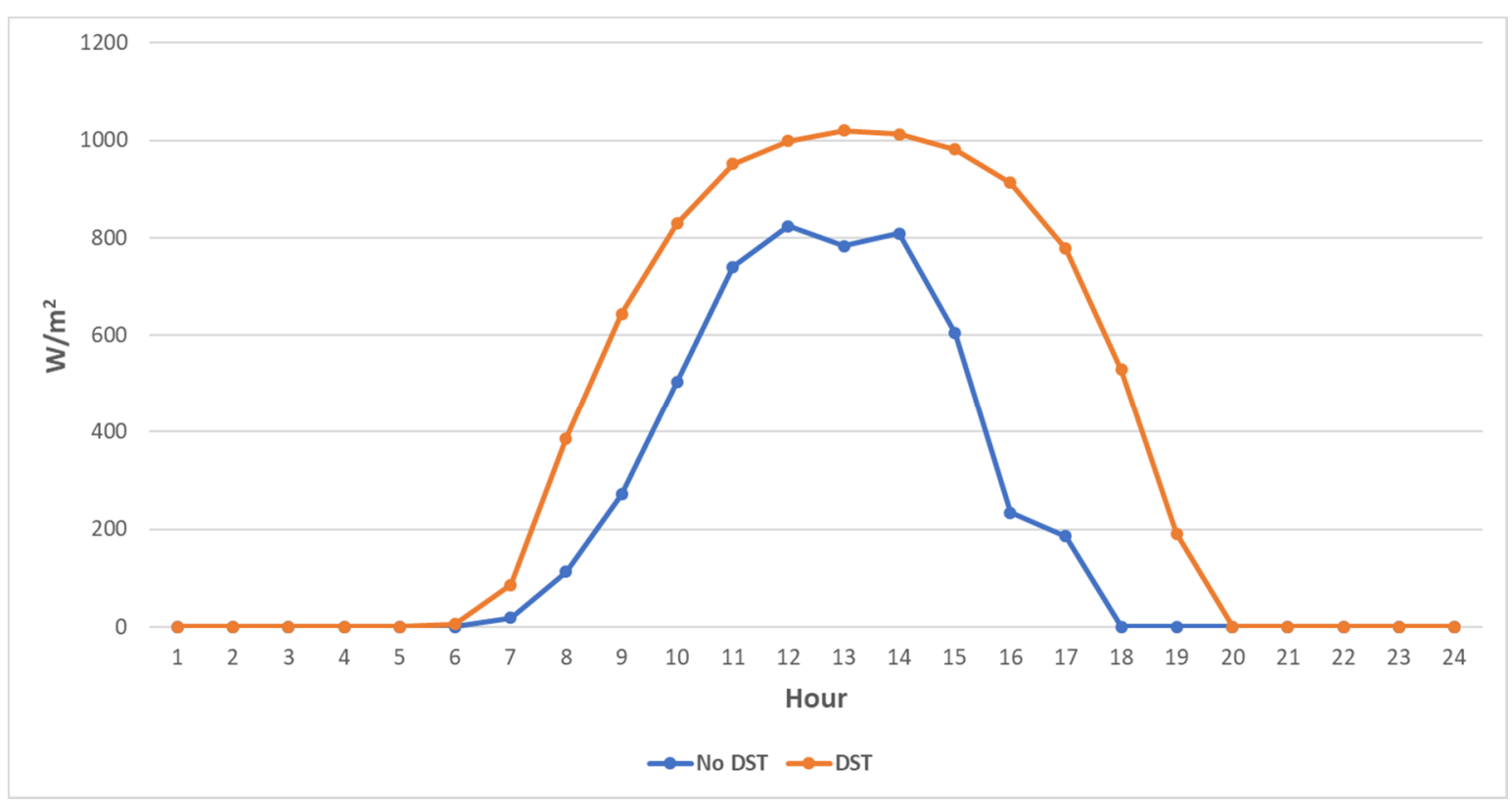

Figure 7. Averaged global solar radiation for the summer solstice (DST) and the winter solstice (no DST) in Mexico in $2018[45]$

In Figure 8, one can observe that the highest generation in scenario A happens at 13:00 h, with a peak generation of 32,000 MW, which represents almost $73 \%$ of the total national demand. In the case of Figure 9, the peak generation happens at 12:00 h, and represents almost $69 \%$ of the total national demand at the same hour for scenario A. 


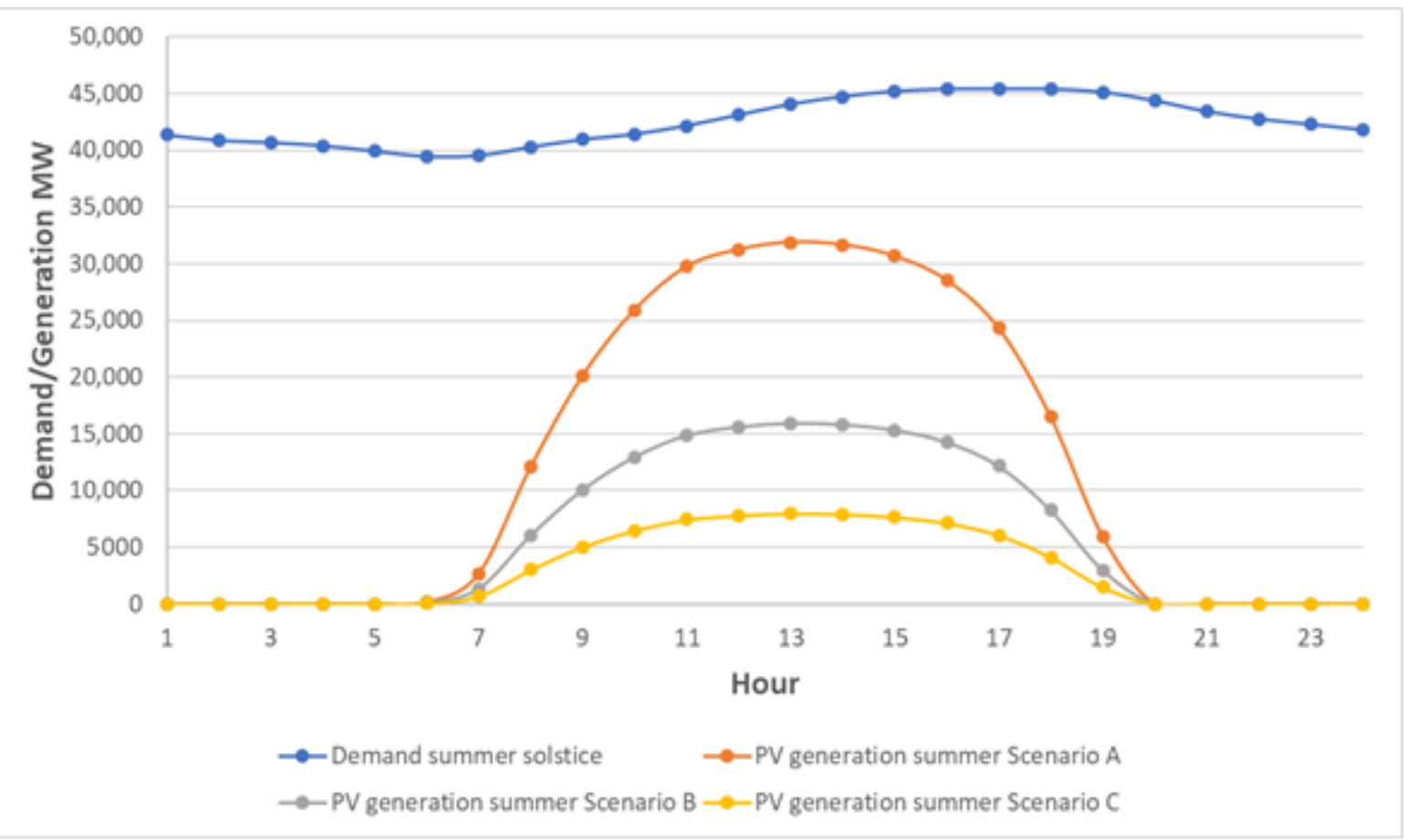

Figure 8. National demand and generation of the three scenarios for 21 June 2018.

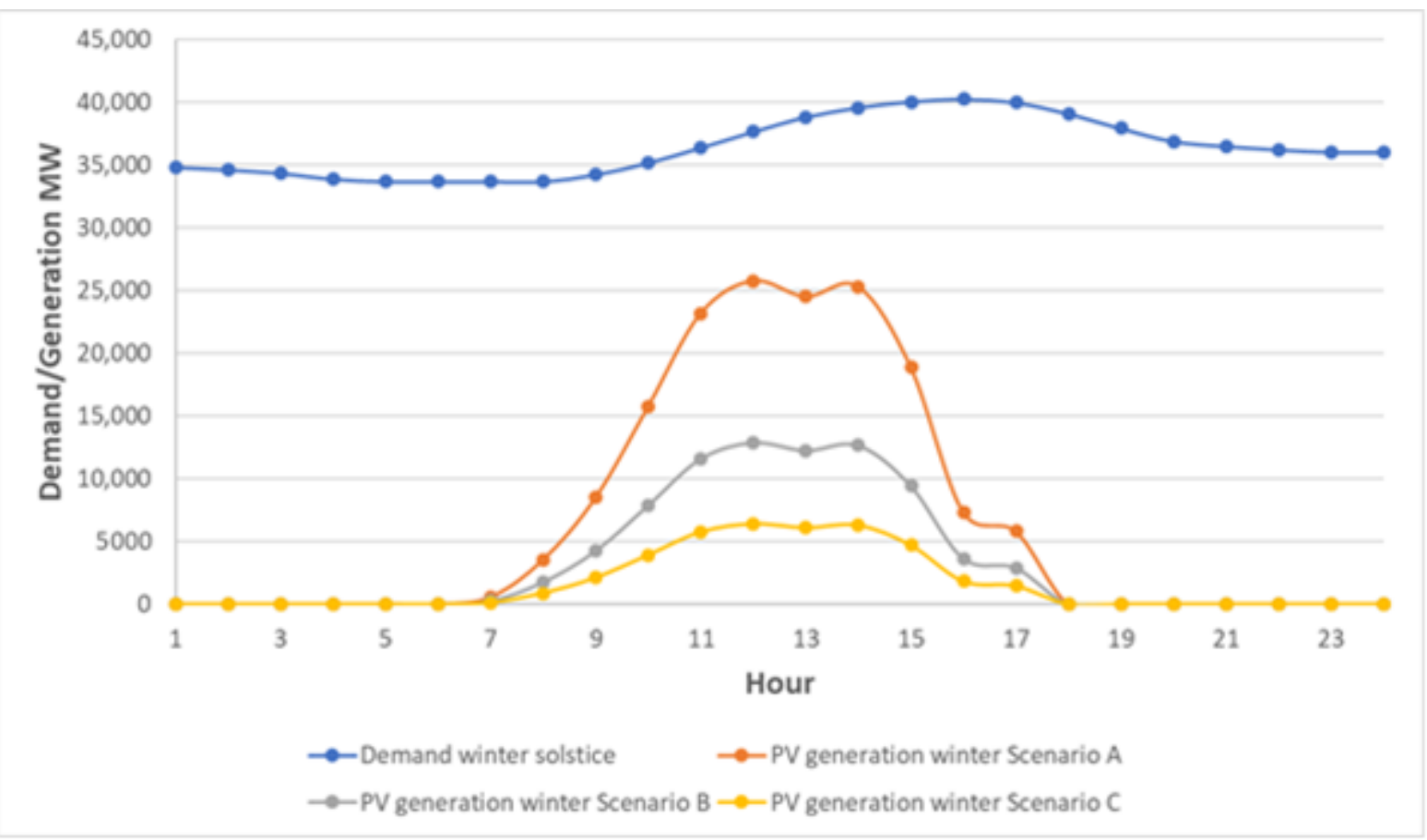

Figure 9. National demand and generation of the three scenarios for 21 December 2018.

Furthermore, for an annual perspective with hourly analysis, Figures 10-12 are displayed for scenarios $A, B$ and $C$, respectively. 


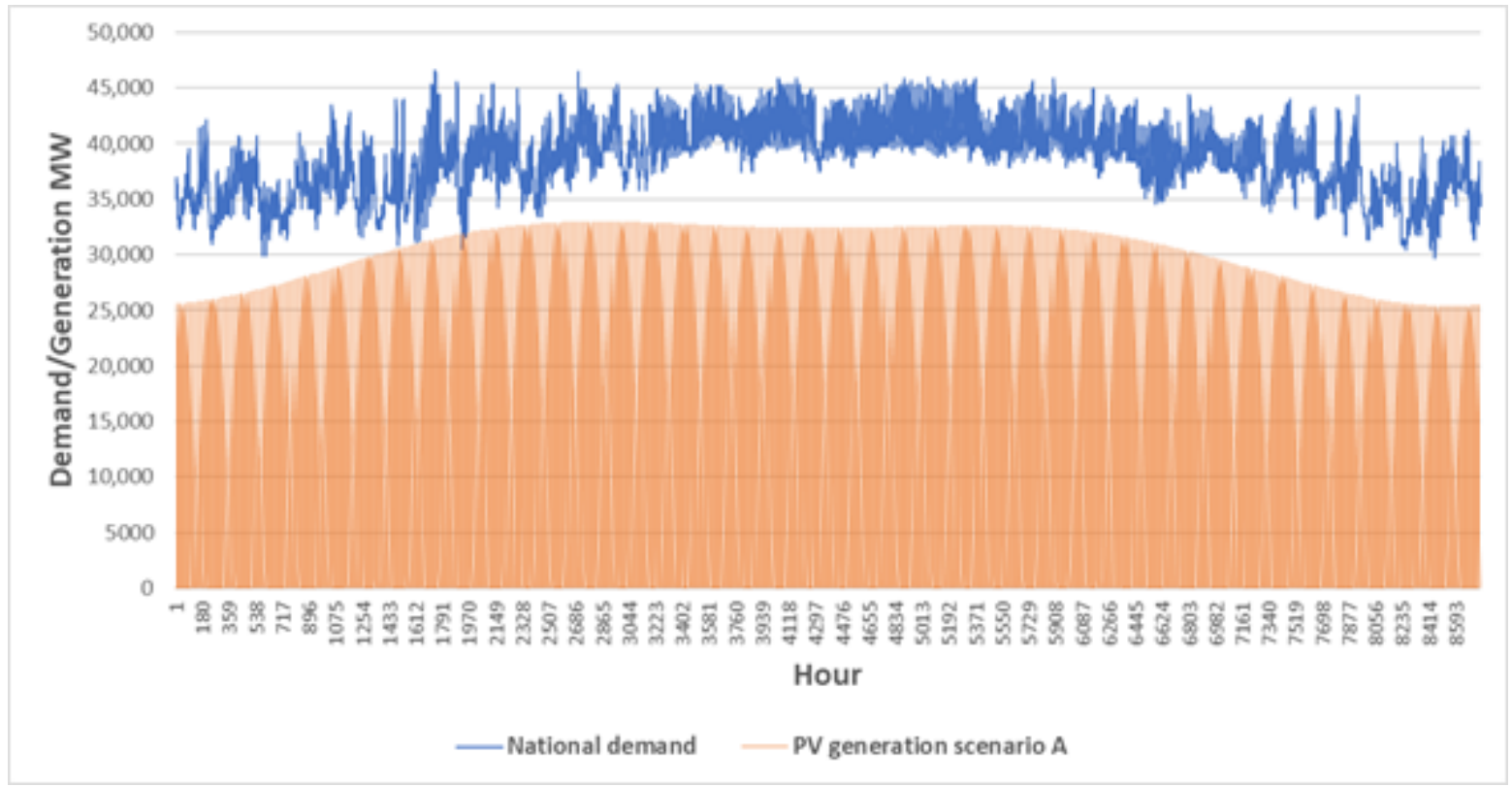

Figure 10. Annual national demand and annual national generation for scenario A in 2018.

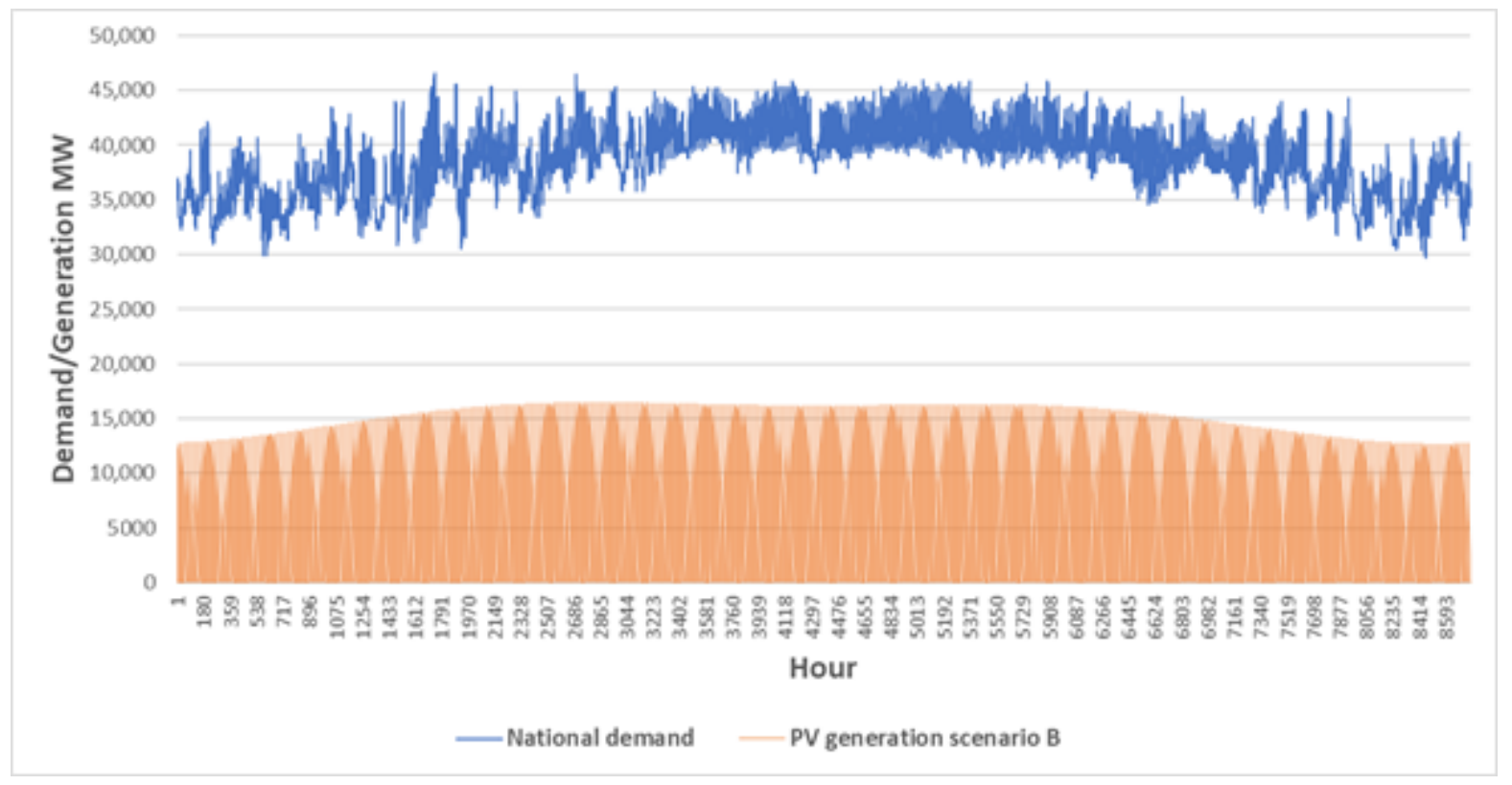

Figure 11. Annual national demand and annual national generation for scenario B in 2018.

From Figures 10-12, one can notice that the generation is highly related to the national global solar radiation, which has higher values during summertime. Moreover, in Figure 10, it can be observed that, during some periods, the PV generation is able to fulfill the total national demand. This is, of course, when certain conditions of low demand and high solar radiation are present in the country. 


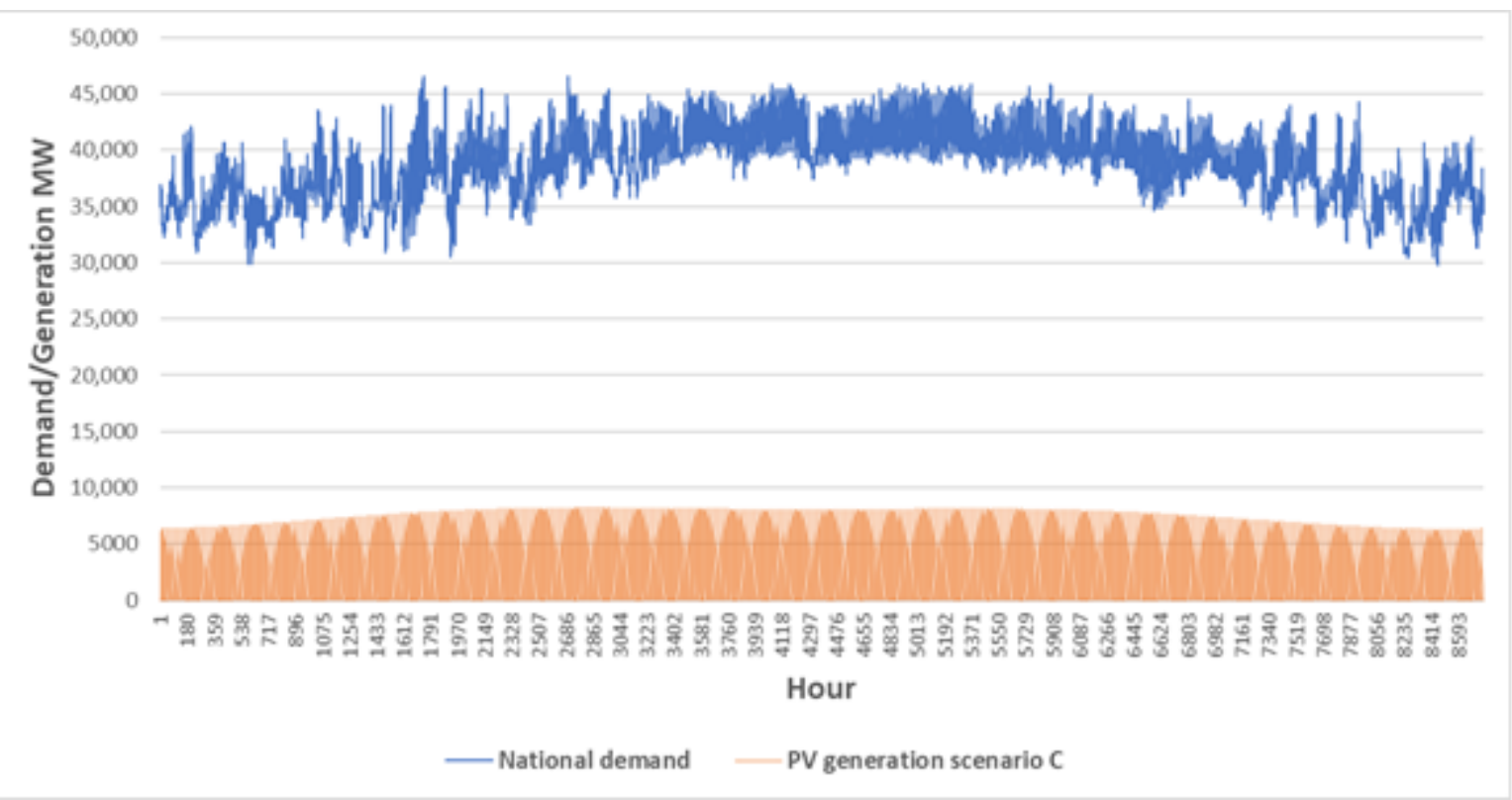

Figure 12. Annual national demand and annual national generation for scenario C in 2018.

\subsection{Validation of the Results}

The validation of the results is given by the comparison of the actual installed capacity and the annual electricity generation of the PV technology in the country. As such, Table 13 was constructed with the installed capacity, the annual electricity generation, and the working hours of the three scenarios developed in this document.

Table 13. Generation of the three proposed scenarios.

\begin{tabular}{cccc}
\hline & $\begin{array}{c}\text { Installed Capacity } \\
\text { (MW) }\end{array}$ & $\begin{array}{c}\text { Annual Generation } \\
\text { (GWh) }\end{array}$ & Working Hours at Year \\
\hline Scenario A & $36,922.9$ & $47,560.9$ & 1288 \\
Scenario B & $19,450.4$ & $23,780.4$ & 1223 \\
Scenario C & 9972.5 & $11,890.2$ & 1192 \\
Actual PV 2018 & 1821 & 2221.0 & 1220 \\
\hline
\end{tabular}

From Table 13, one can notice that the working hours in the three scenarios-the result of the ratio between the annual generation and the installed capacity-have a similar order of magnitude to the actual working hours presented in Mexico in 2018.

Moreover, for the total number of dwellings according to the correspondent architype, a total consumption of $62,205.9 \mathrm{GWh}$ is estimated. In this sense, it is considered that the distribution of dwellings is given by the following: 3,195,697 for Architype 1, 24,836,121 for Architype 2, and 6,704,016 for Architype 3, with a total of 34,735,833 dwellings. As such, with Table 8 , the correspondent consumption of each architype is multiplied by the respective number of dwellings, and the total consumption of $62,205.9 \mathrm{GWh}$ is hence estimated. If the actual consumption of the Mexican residential sector in 2018 (62,000 GWh) is compared with the consumption calculated in this document, it can be concluded that the model developed here estimates, in a proper manner, the energy consumption, and thus the generation, in the Mexican residential sector.

\section{Discussion}

\subsection{Environmental Benefits}

If the proposed approach were applied in the country, there would be a certain environmental benefit, reflected mainly in the $\mathrm{CO}_{2}$ mitigation. As such, by considering the 
$\mathrm{CO}_{2}$-equivalent $\left(\mathrm{CO}_{2} \mathrm{e}\right)$ emission factor of the Mexican generation plants in 2018, i.e., 0.527 $\mathrm{TonCO}_{2} \mathrm{e} / \mathrm{MWh}$ [51], and assuming that the total generation of the PV roofs replaces the generation by the fossil-fuel-based technologies, Table 14 can be constructed.

Table 14. Mitigation of TonCO $\mathrm{C}_{2}$ e by installing PV roofs extensively in Mexico in 2018.

\begin{tabular}{cc}
\hline & TonCO $\mathbf{C}_{\mathbf{2}}$ e Mitigated \\
\hline Scenario A & $25,064,594$ \\
Scenario B & $12,532,271$ \\
Scenario C & $6,266,135$ \\
\hline
\end{tabular}

The mitigation presented in any scenario is much higher than the Horario de Verano program, which-in 2018-had a $\mathrm{CO}_{2}$ eq mitigation of 498 thousand tons [47], with an energy saving of $945.29 \mathrm{GWh}$ [47]. As a matter of fact, the actual PV generation in 2018 alone was 2.3 times higher than the mentioned governmental program. This reaffirms the necessity of using innovative approaches of renewable energies beyond national saving programs that seem to be insufficient by themselves for achieving the signed international agreements of $\mathrm{CO}_{2}$ eq reduction.

\subsection{Economic Benefits}

By considering the average price of MWh generated in Mexico in 2018 as 71.88 USD [52], calculated by the Mexican Escrow for Saving Electricity (FIDE, acronym in Spanish), the money saving in each scenario can be seen in Table 15.

Table 15. Money saving by installing PV roofs extensively in Mexico in 2018.

\begin{tabular}{lc}
\hline & USD Million \\
\hline Scenario A & 3418 \\
Scenario B & 1709 \\
Scenario C & 854 \\
\hline
\end{tabular}

From Table 15, one can conclude that any of the three scenarios provides high money savings compared to other annual-based savings, such as the Horario de Verano (67.95 USD Million [47]), or the extensive use of natural ventilation in Mexico (900 USD Million [48]).

\subsection{Economic and Technical Feasibility}

Any of the presented scenarios could be financed by a governmental program, such as the Horario de Verano, or the substitution of incandescent lightbulbs and/or obsolete refrigerators [47], as were carried out in previous years. Alternatively, it could perhaps be an association between the governmental programs, through the Ministry of Energy, and the private initiative, through renewable-energy companies, which have been willing to invest in Mexico since the Energy Reform of 2013. Moreover, the final consumer, as the center of the trade, could provide an impulse for the projects by investing on their own PVroofs, as well as by looking for financing from the aforementioned governmental programs, or even from financial entities such as banks [44].

In any case, any stakeholder is able to receive money savings and/or profits. Governmental entities and final consumers can save money by not using the energy that is not produced, freeing the transmission grid in the case of the CENACE, and lowering the electricity bills, in the case of the final consumers. On the other hand, clean-energy producers can increase their production, cheapening the costs of this kind of energy production.

On the subject of technical feasibility, the SEN, and especially the distribution grid, is already prepared to exchange generated electricity, as is shown in the issued law of Residential Distributed Generation Power Plants and Distributed Clean Generation lower than 0.5 MW, with an interconnection contract with CFE through the filial CFE Basic Services Provider [53]. 
The framework of the law considers that the generated electricity by the PV roofs has to be distributed through the distribution grid, with voltages of 1-35 kV, amongst consumers located near the residential power plant [53]. In this sense, the three schemes of managing the generated electricity by the residential power plants (PV-roofs) are the following:

- Net Metering: the customer consumes and generates energy in the same supply contract. This energy is offset against each other, and a single billing is issued.

- Net Billing: the energy consumed that CFE bills towards the customer is independent of the energy that the customer generates and sells to the CFE; that is, it is not compensated. The consumed electricity must be associated with a supply contract.

- Total Energy Sale: the client sells all of the energy generated to the CFE. There is no customer supply contract with the CFE.

For the purposes of this document, the Net Metering contract best suits the interconnection and exchange of electricity between the producer (household) and distributer (CENACE), producing an energy balance of production and consumption. In the case of the Net Billing and Total Energy Sale schemes, CENACE could not carry out this energy balance due to the lack of information of the electricity generation by the households. Moreover, in the scheme of Total Energy Sale, it is implied that a device of energy storage would be needed in order to dispatch the energy necessities of the dwelling, meaning that the proposed approach would be more expensive and difficult to implement.

As such, the benefits of the proposed strategy rely on the economical saving, mostly of the final users, and the environmental benefits, which are more focused on the national scenario, reducing the millions of $\mathrm{TonCO}_{2} \mathrm{eq}$ released into the atmosphere, reaching-in a faster manner - the signed agreements, such as Paris and Kyoto.

Finally, the feasibility of the implementation of the approach depends on the technical capability of the SEN and CENACE. In this sense, these Mexican institutions already have the technology in certain regions of the country, awaiting the expansion to the total national territory in the coming years.

\section{Conclusions}

In Mexico, the issue of the lack of priority given by the CFE to renewable energy production was addressed in this document by the proposal of the extensive use of on-site PV cells in the Mexican residential sector. An additional purpose of the proposal was to liberate the transmission grid by generating clean energy at the very same place where it is consumed, thereby avoiding the electricity loss throughout the SEN.

Moreover, the technology for carrying out this generation-consumption relationship has already settled on Mexico through the CENACE, which is the system in charge of balancing the generated energy, generally from large power plants (above $200 \mathrm{MW}$ of installed capacity), and the final consumers. For this, the CENACE uses the SEN, leaving only three relatively small interconnected systems in the Baja California Peninsula to manage their own generation-consumption.

Therefore, this disadvantage of the SEN with respect to random renewable energies is addressed by the use of extensive on-site generation in the Mexican residential sector. As the Mexican government already has three kinds of schemes for an energy trade between small producers and the CFE (Net Metering, Net Billing, and Total Energy Sale), the scheme of Net Metering was hereby proposed to distribute the instant energy production from the residential roofs amongst their nearby consumers, using the distribution grid of the SEN.

In this sense, it was found that the three scenarios proposed in this document, considering the different levels of penetration into the Mexican housing sector, achieved promising benefits, both environmental and economic. For Scenario A, 3418 Million USD and 25 Million TonCO $\mathrm{C}_{2}$ e could be saved and mitigated, respectively; whereas, for Scenarios $B$ and $C$, the money saving and the $\mathrm{CO}_{2}$ mitigation could be 1709 Million USD and 12.5 Million TonCO $\mathrm{C}_{2} \mathrm{e}$, and 854 Million USD and 6.2 Million Ton $\mathrm{CO}_{2} \mathrm{e}$, respectively. Furthermore, the initial investments seem affordable if there is a collaboration among the 
main stakeholders, namely the government, private initiatives and final consumers, which always show the multiple benefits that come with this national approach.

As a final comment, it should be mentioned that the extensive simultaneous use of PV generation in a national scenario, such as that presented here, could be carried out if the transmission and distribution grid is highly interconnected, which is the case in Mexico. When a national electricity system has several regional insolated grids, an independent analysis has to be carried on for every regional system.

Author Contributions: I.O.-P. developed the idea of implementing PV roofs in the Mexican housing sector, and produced the analysis of the implementation. A.H.P.-R. estimated the environmental and economic benefits. All of authors have read and agreed to the published version of the manuscript.

Funding: This research received no external funding.

Institutional Review Board Statement: Not applicable.

Informed Consent Statement: Not applicable.

Data Availability Statement: Data available in a publicly accessible repository that does not issue DOIs. Publicly available datasets were analyzed in this study. This data can be found here: https://www.cenace.gob.mx/Paginas/Publicas/Planeacion/ProgramaRNT.aspx.

Conflicts of Interest: The authors declare no conflict of interest.

\section{Nomenclature}

$G_{\text {Instant }}$
$N G_{\text {Scenario }}$
$P V_{\text {eff }}$
$P V_{\text {Surface }}$ Architype $n$
$P_{\text {in }}$
$P_{\text {out }}$
$R_{\text {Mean }}$

Instant generation by PV cell [W] National instant generation by PV cells [MW] Efficiency of the PV cell [dimensionless] Surface of the PV cell according to the architype $\left[\mathrm{m}^{2}\right]$ Solar input power [kWh] Electrical output power [kWh] Mean national global solar radiation of Mexico at one hour in specific $\left[\mathrm{W} / \mathrm{m}^{2}\right]$

\section{References}

1. Capitanescu, F. Evaluating reactive power reserves scarcity during the energy transition toward $100 \%$ renewable supply. Electr. Power Syst. Res. 2021, 190, 106672. [CrossRef]

2. Bacekovic, I.; Ostergaard, P.A. Local smart energy systems and cross-system integration. Energy 2018, 151, 812-825. [CrossRef]

3. Bacekovic, I.; Ostergaard, P.A. A smart energy system approach vs a non-integrated renewable energy system approach to designing a future energy system in Zagreb. Energy 2018, 155, 824-837. [CrossRef]

4. Takao, Y. Low-carbon leadership: Harnessing policy studies to analyse local mayors and renewable energy transitions in three Japanese cities. Energy Res. Soc. Sci. 2020, 69, 101708. [CrossRef]

5. Thellufsen, J.Z.; Nielsen, S.; Lund, H. Implementing cleaner heating solutions towards a future low-carbon scenario in Ireland. J. Clean. Prod. 2019, 214, 377-388. [CrossRef]

6. Jung, T.; Park, C. Low-carbon scenarios for the power generation sector in Korea. J. Renew. Sustain. Energy 2017, 9, 021403. [CrossRef]

7. Thellufsen, J.Z.; Lund, H.; Sorknaes, P.; Ostergaard, P.A.; Chang, M.; Drysdale, D.; Nielsen, S.; Djorup, S.R.; Sperling, K. Smart energy cities in a 100\% renewable energy context. Renew. Sustain. Energy Rev. 2020, 129, 109922. [CrossRef]

8. Bompard, E.; Botterud, A.; Corgnati, S.; Huang, T.; Jafari, M.; Leone, P.; Mauro, S.; Montesano, G.; Papa, C.; Profumo, F. An electricity triangle for energy transition: Application to Italy. Appl. Energy 2020, 227, 115525. [CrossRef]

9. Israel, A.; Herrera, R.J. The governance of Peruvian energy transitions: Path dependence, alternative ideas and change in national hydropower expansion. Energy Res. Soc. Sci. 2020, 69, 101608. [CrossRef]

10. Murshed, M.; Chadni, M.H.; Ferdaus, J. Does ICT facilitate renewable transition and environmental sustainability? Evidence from Bangladesh, India, Pakistan, Sri Lanka, Nepal and Maldives. Energy Ecol. Environ. 2020, 5, 470-495. [CrossRef]

11. Rasiah, R.; Al-Amin, A.Q.; Ahmed, A.; Filho, W.L.; Calvo, E. Climate mitigation roadmap: Assessing low carbon scenarios for Malaysia. Energy. J. Clean. Prod. 2016, 133, 272-283. [CrossRef]

12. Lima, F.; Portugal-Pereira, J.; Lucena, A.F.P.; Rochedo, P.; Cunha, J.; Lopes Nunes, M.; Szklo, A.S. Analysis of energy security and sustainability in future low carbon scenarios for Brazil. Nat. Resour. Forum 2015, 39, 175-190. [CrossRef]

13. Banacloche, S.; Herrera, I.; Lechon, Y. Towards energy transition in Tunisia: Sustainability assessment of a hybrid concentrated solar power and biomass plant. Sci. Total Environ. 2020, 744, 140729. [CrossRef] [PubMed] 
14. Adewuyi, O.B.; Kiptoo, M.K.; Afolayan, A.F.; Amara, T.; Alawode, O.I.; Senjyu, T. Challenges and prospects of Nigeria's sustainable energy transition with lessons from other countries' experiences. Energy Rep. 2020, 6, 993-1009. [CrossRef]

15. Baek, Y.J.; Jung, T.Y.; Kang, S.J. Low carbon scenarios and policies for the power sector in Botswana. Clim. Policy 2019, 19, 219-230. [CrossRef]

16. Sharmina, M. Low-carbon scenarios for Russia's energy system: A participative backcasting approach. Energy Policy 2017, 104, 303-315. [CrossRef]

17. Koltsaklis, N.E.; Dagoumas, A.S.; Seritan, G.; Porumb, R. Energy transition in the South East Europe: The case of the Romanian power system. Energy Rep. 2020, 6, 2376-2393. [CrossRef]

18. Hafner, S.; Anger-Kraavi, A.; Monasterolo, I.; Jones, A. Emergence of new economics energy transition models: A review. Ecol. Econ. 2020, 177, 106779. [CrossRef]

19. Blazquez, J.; Fuentes, R.; Manzano, B. On some economic principles of the energy transition. Energy Policy 2020, $147,111807$. [CrossRef]

20. Garcia-Garcia, P.; Carpintero, O.; Buendia, L. Just energy transitions to low carbon economies: A review of the concept and its effects on labour and income. Energy Res. Soc. Sci. 2020, 70, 101664. [CrossRef]

21. Pons-Seres de Brauwer, C.; Cohen, J.J. Analyzing the potential of citizen-financed community renewable energy to drive Europe's low-carbon energy transition. Renew. Sustain. Energy Rev. 2020, 133, 110300. [CrossRef]

22. Heras, J.; Martin, M. Social issues in the energy transition: Effect of the design of the new power system. Appl. Energy 2020, 278, 115654. [CrossRef]

23. Martinez, N.; Komendantova, N. The effectiveness of the social impact assessment (SIA) in energy transition management: Stakeholders' insights from renewable energy projects in Mexico. Energy Policy 2020, 145, 111744. [CrossRef]

24. Nieto, J.; Carpintero, O.; Lobejon, L.F.; Miguel, L.J. An ecological macroeconomics model: The energy transition in the EU. Energy Policy 2020, 145, 111726. [CrossRef]

25. Smith, I.D. How the process of transitions shapes the politics of decarbonization: Tracing policy feedback effects across phases of the energy transition. Energy Res. Soc. Sci. 2020, 70, 101753. [CrossRef]

26. Vanegas Cantarero, M.M. Of renewable energy, energy democracy, and sustainable development: A roadmap to accelerate the energy transition in developing countries. Energy Res. Soc. Sci. 2020, 70, 101716. [CrossRef]

27. Zhao, N.; You, F. Can renewable generation, energy storage and energy efficient technologies enable carbon neutral energy transition? Appl. Energy 2020, 279, 115889. [CrossRef]

28. Neofytou, H.; Nikas, A.; Doukas, H. Sustainable energy transition readiness: A multicriteria assessment index. Renew. Sustain. Energy Rev. 2020, 131, 109988. [CrossRef]

29. Vakulchuk, R.; Overland, I.; Scholten, D. Renewable energy and geopolitics: A review. Renew. Sustain. Energy Rev. 2020, 122, 109547. [CrossRef]

30. Jenner, S.; Chan, G.; Frankenberger, R.; Gabel, M. What drives states to support renewable energy? Energy J. 2012, 33, 12-24. [CrossRef]

31. Lund, H.; Ostergaard, P.A.; Conolly, D.; Mathiesen, B.V. Smart energy and smart energy systems. Energy 2017, 137, 556-565. [CrossRef]

32. Latif, A.; Hussain, S.M.S.; Das, D.C.; Ustun, T.S. State-of-the-art of controllers and soft computing techniques for regulated load frequency management of single/multi-area traditional and renewable energy based power systems. Appl. Energy 2020, 266, 114858. [CrossRef]

33. Latif, A.; Das, D.C.; Barik, A.K.; Ranjan, S. Maiden coordinated load frequency control strategy for ST-AWEC-GEC-BDDG-based independent three-area interconnected microgrid system with the combined effect of diverse energy storage and DC link using BOA-optimised PFOID controller. ET Renew. Power Gener. 2019, 13, 2634-2646. [CrossRef]

34. Syranidou, C.; Linssen, J.; Stolten, D.; Robinius, M. Integration of large-scale variable renewable energy sources into the future European power system: On the curtailment challenge. Energies 2020, 13, 5490. [CrossRef]

35. Vidal-Amaro, J.J.; Ostergaard, P.A.; Sheinbaum-Pardo, C. Optimal energy mix for transitioning from fossil fuels to renewable energy sources-The case of the Mexican electricity system. Appl. Energy 2015, 150, 80-96. [CrossRef]

36. Vidal-Amaro, J.J.; Ostergaard, P.A.; Sheinbaum-Pardo, C. Analysis of large-scale integration of renewable energy sources in the Mexican electricity system. Trans. Ecol. Environ. 2015, 195, 449-461.

37. Diezmartinez, C.V. Clean energy transition in Mexico: Policy recommendations for the deployment of energy storage technologies. Renew. Sustain. Energy Rev. 2021, 135, 110407. [CrossRef]

38. Centro Nacional de Control de Energía. Programa de Ampliación y Modernización de la Red Nacional de Transmisión y Redes Generales de Distribución del Mercado Eléctrico Mayorista. Available online: https://www.cenace.gob.mx/Paginas/Publicas / Planeacion/ProgramaRNT.aspx (accessed on 20 November 2020).

39. Wood, D. Mexico's New Energy Reform; Wilson Center Mexico Institute: Washington, DC, USA, 2018.

40. Centro Nacional de Control de Energía. Gráfica de Demanda. Available online: https://www.cenace.gob.mx/GraficaDemanda. aspx (accessed on 16 November 2020).

41. Gobierno de México. Secretaría de Energía. El Gobierno Fortalece el Sistema Eléctrico Nacional. 16 de Mayo de 2020. Available online: https://www.gob.mx/sener/es/articulos/el-gobierno-de-mexico-fortalece-el-sistema-electrico-nacional (accessed on 2 November 2020). 
42. Instituto Nacional de Estadística, Geografía e Informática. Encuesta Nacional de Ingresos y Gastos de los Hogares 2018. Available online: https://www.inegi.org.mx/contenidos/programas/enigh/nc/2018/doc/enigh2018_ns_presentacion_resultados.pdf (accessed on 20 November 2020).

43. Comisión Nacional de Vivienda. Padrón de Verificadores de Obra de la Comisión Nacional de Vivienda. Available online: https:/ / www.gob.mx/conavi/documentos / padron-de-verificadores-de-obra-de-la-comision-nacional-de-vivienda (accessed on 14 November 2020).

44. Mexican National Association of Solar Energy. Monitor de información comercial e índice de precios de Generación Solar Distribuida en México. Available online: https://anes.org.mx/wp-content/uploads/2020/04/Estudio_primer-monitor-deinformacio \%CC \%81n-comercial-e-i\%CC\%81ndice-de-precios-de-Generacio\%CC\%81n-Solar-Distribuida-GSDANES_AMIF_ ASOLMEX_GIZ.pdf (accessed on 14 October 2020).

45. Global Solar Atlas. Available online: https://globalsolaratlas.info/download/mexico (accessed on 10 November 2020).

46. Sharma, V.; Kaur, H.; Kaur, I. Design and implementation of multi-junction PV cell for MPPT to improve the transformation efficiency. Int. J. Recent Technol. Eng. 2019, 7, 248-253.

47. Comisión Nacional para el Uso Eficiente de la Energía. Programas de Ahorro de Energía en México. Available online: https: / / www.jetro.go.jp/mexico/topics/20091216142-topics/Programa_Ahorro_Energia_Mexico.pdf (accessed on 30 October 2020).

48. Oropeza-Perez, I.; Ostergaard, P.A. Energy saving potential of utilizing natural ventilation under warm conditions-A case study of Mexico. Appl. Energy 2014, 130, 20-32. [CrossRef]

49. Oropeza-Perez, I.; Petzold-Rodriguez, A.H. Analysis of the energy use in the Mexican residential sector by using two approaches regarding the behavior of the occupants. Appl. Sci. 2018, 8, 2136. [CrossRef]

50. Centro Nacional de Metrología. Hora Oficial. Available online: https://www.cenam.mx/hora_oficial/ (accessed on 14 September 2020).

51. Comisión Reguladora de Energía. Aviso Sobre el Factor de Emisión Eléctrico para el Reporte 2018. Available online: https: / / www.gob.mx/cms/uploads/attachment/file/442910/Aviso_Factor_de_Emisiones_2018.pdf (accessed on 24 October 2020).

52. Centro Nacional de Control de Energía. Precios Marginales Locales. Available online: https://www.cenace.gob.mx/Paginas / SIM/Reportes/PreciosEnergiaSisMEM.aspx (accessed on 23 October 2020).

53. Comisión Federal de Electricidad. Contratación de Servicios Fotovoltaicos. Available online: https://www.cfe.mx/Casa/ InformacionCliente/Pages/Contrataci\%C3\%B3n-de-servicios-Fotovoltaicos.aspx (accessed on 12 October 2020). 